\title{
Language Functions in the Speech of Queen Elizabeth Ii during the Trying Times of Coronavirus: A Hallidayan Approach
}

\author{
N. Beatrice M'po Kouyinampou ${ }^{1 *}$
}

${ }^{1}$ Université d'Abomey-Calavi, (UAC) Bénin

DOI: $10.36347 /$ sjahss.2021.v09i03.003

| Received: 02.03.2021 | Accepted: 19.03.2021 | Published: 28.03.2021

*Corresponding author: N. Beatrice M'po Kouyinampou

Abstract

Original Research Article

This article explores the functions of language in the speech of Great Britain's Queen Elizabeth II during the trying times of coronavirus. The purpose to achieve is to disclose how, through language and her choice of words, Queen Elizabeth II addresses her people about covid19 Using the Hallidayan approach, the analysis is premised on the speech delivered by Queen Elisabeth II on the $5^{\text {th }}$ April 2020. It is found that Coronavirus pandemic influences the use of language by Queen Elizabeth II. Throughout her speech, she reveals the difficulties of the time and has some encouragement words toward her citizens.

Keywords: Language, Context, Coronavirus, Systemic Functional Linguistics.

Copyright $\odot 2021$ The Author(s): This is an open-access article distributed under the terms of the Creative Commons Attribution 4.0 International License (CC BY-NC 4.0) which permits unrestricted use, distribution, and reproduction in any medium for non-commercial use provided the original author and source are credited.

\section{INTRODUCTION}

Language is used by human beings to communicate or to interact with others. Through it, people express their ideas, feelings, emotions. Language can be spoken or written. Underling the importance of language in human beings' life, Fontaine [1] cogently argues that "There is little we do in this life that does not involve language" (p.237). Linguistics, which is the scientific study of language, reveals what are language and its functions. And, Applied Linguistics deals with the application of linguistic theories to corpora.

Systemic Functional Linguistics, as contended by Eggins [2], is increasingly recognised as a very useful descriptive and interpretative framework for viewing language as a strategic, meaning-making resource. It must be noted that Systemic Functional Linguistics (henceforth SFL) has been used in recent years to say 'sensible and useful things' in different areas or fields. SFL theory has been used in Discourse Analysis, Applied Linguistics, Sociolinguistics and Contrastive studies as well as in many other disciplines.

Since December 2019, in Wuhan in China, appeared a virus. But in 2020, it is witnessed that this virus bewilders the world. Initially known as a mere epidemic, covid-19 (from the coronavirus family) was declared a pandemic by the World Health Organization (WHO) which proclaimed a health emergency of international concern. Almost all the leaders of the globe, especially presidents, at least addressed some speeches to their populations to reassure them about their capacity to grapple with the pandemic. In that respect, Queen Elizabeth II has proven to be no exception in her management of the crisis.

This article intends to analyse her speech about the virus. It basically seeks to disclose how, through language and her choice of words, Queen Elizabeth II addresses her people about covid19. To achieve this broad goal, the following research questions are asked:

- How does language function in the speech of Queen Elizabeth II?

- Under what circumstances and how does she face this pandemic?

- What contribution can the Halliday theory make to the understanding of this speech?

- What types of meaning are encoded in through the language choice?

The speech will be analysed on the Hallidayan perspective. The results will be numerically tabularized, and then the findings drawn from the analysis will be discussed. Before indulging in the analysis proper, it is important to broach the theory which underpins the research work and to define some key concepts. 


\section{A brief theoretical framework and conceptual clarification \\ 1.1 Language and context}

Halliday [3] developed the lexico-grammatical patterns. For him, language is structured to make three kinds of meaning, namely: experiential meaning (about how people represent experience in language), interpersonal meaning (about the role relationship with other people in communication) and textual meaning (about the organization of information conveyed in communication). And Eggins, one of his followers [2] contends that the three register variables (field, mode and tenor) leads respectively to Transitivity, Theme, and Mood patterns which are expressed through the Grammar of Experiential Meaning, the Grammar of Textual Meaning and the Grammar of Interpersonal Meaning.

Systemic Functional Linguistics is the study of the relationship between language and its function in social settings. It is also known as SFL, Systemic Functional Grammar, Hallidayan linguistics and Systemic Linguistics. Systemic Functional Linguistics was developed in the 1960 s by the British linguist M.A.K Halliday (born in 1925), who had been influenced by the work of the Prague School and the British linguist J.R. Firth (1890 -1960)

The approach being concerned with the study of language in a social environment, it also takes into account how meanings are made in context. Albeit the social environment in which people live has an impact on the language in use, language likewise plays an important role in the evolution of culture. In the Hallidayan perspective, language can be seen as ways of meaning making, ways to mean which builds the social systems. Language is an organized meaning making resource and there is an interrelation between form and meaning. So language is the only semiotic system which evolves in our culture [3]. Systemic Functional Linguistics has developed a comprehensive theoretical foundation since 1960 by Halliday [4], Halliday and Matthiessen [6, 5], Eggins [7, 2], Fontaine [1] and so on. In this section I review the dimensions which are appropriate to this study, including the stratification and the lexicogrammar.

Halliday \& Matthiessen [5] asserts that language is a complex semiotic system, having various levels or strata. So stratification relates to different levels of reality on a cline of abstraction. To say one thing, there may be alternative modes of expression, one of sounding and one of writing. So the strata depend on who uses language and for what purpose. Then, the 'contend' expands into two, a lexicogrammar and a semantics [4, a; Halliday and Matthiessen [6]; cited in Halliday \& Matthiessen [5]. Lexicogrammar is concerned with making meanings through the clause and discourse semantics is making meanings in the discourse of whole texts. Moreover, Firth (1935, cited in Halliday \& Hassan [4] claims that all linguistics is the study of meaning and all meaning is function in a context. This means that when we study text, we need to look at the environment in which it unfolds or its context. Simply said in the words of Halliday and Matthiessen [5], language operates in context. Context precedes text. Since context precedes text, so what is text? According to Eggins [7]. "The term "text" has been glossed as 'authentic products of social interaction". As for Halliday and Hasan [4, 1], cited in Eggins [2], "The word TEXT is used in linguistics to refer to any passage, spoken or written, of whatever length, that does form a united whole."

With context, there are two levels: genre and register. Genre theory is about bringing the unconsciousness of cultural knowledge to consciousness by describing how language is used to do things. Eggins [2] contends that the concept of genre is "the impact of the context of culture on language, by exploring the staged, step-by-step structure cultures institutionalize as ways of achieving goals". Eggins quotes Martin's definition of genre as a "staged, goaloriented, purposeful activity in which speakers engage as members of our culture" (2004: 55). For Bock (2007), genres are socially recognized, patterned ways of achieving certain social goals, such as buying a newspaper or chatting to friends. SFL theorists argue that within each genre, certain predictable configurations of the three register variables, field, tenor and mode, occur as habitual ways of interacting appropriately within that culture [2].

Halliday contends that the "context of situation" seeks to describe the systemic relationship in terms of three dimensions, referred to as the field, tenor and mode [8]. In SFL, the context of situation is referred to as the register theory. And the field, tenor and Mode are called the register variables. Field refers to "what the language is being used to talk about". Tenor is about "the role relationships between the interactants"; and Mode refers to "the ways texts are structured and organized." These three variables are called the register variables, and a description of the values for each of these variables at a given time of language use is a register description of a text [2]. There is a relationship between the register variables and the use of language to the social processes in our culture. This is shown in the following figure: 


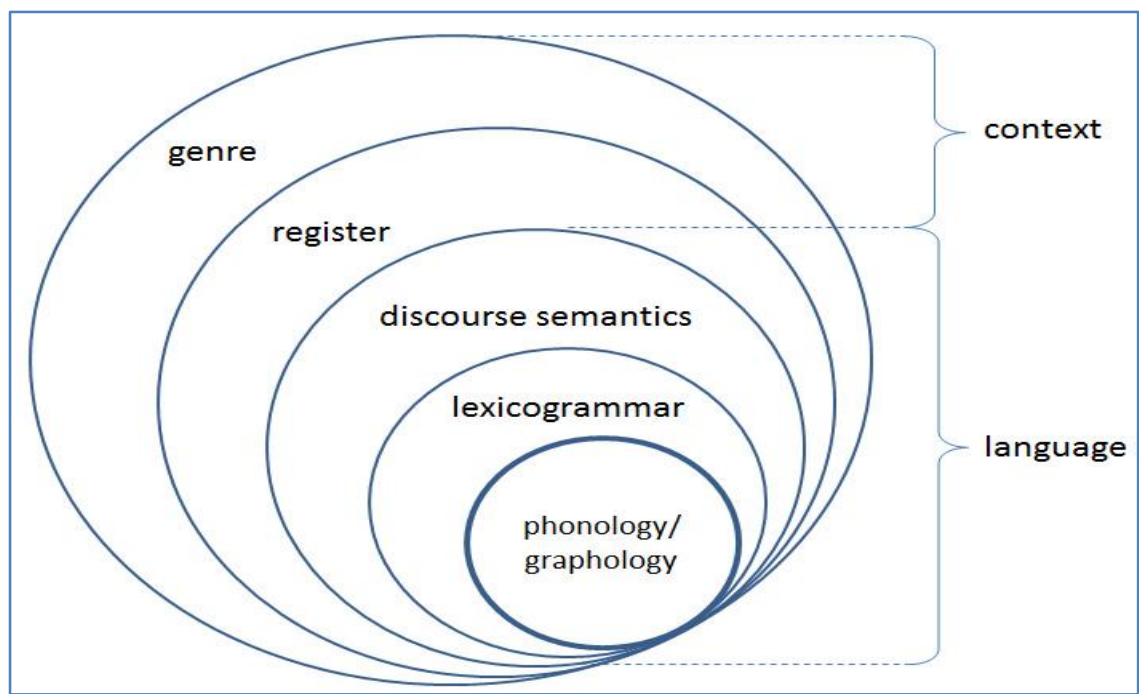

Fig-1: Stratification of language and context (Adapted from Martin 1992) (From Hao, 2015)

This is more explained in figure 2 beneath which considers context as a single stratum in language as stated by some linguists. For them, context is not a matter of strata but it is only one stratum:

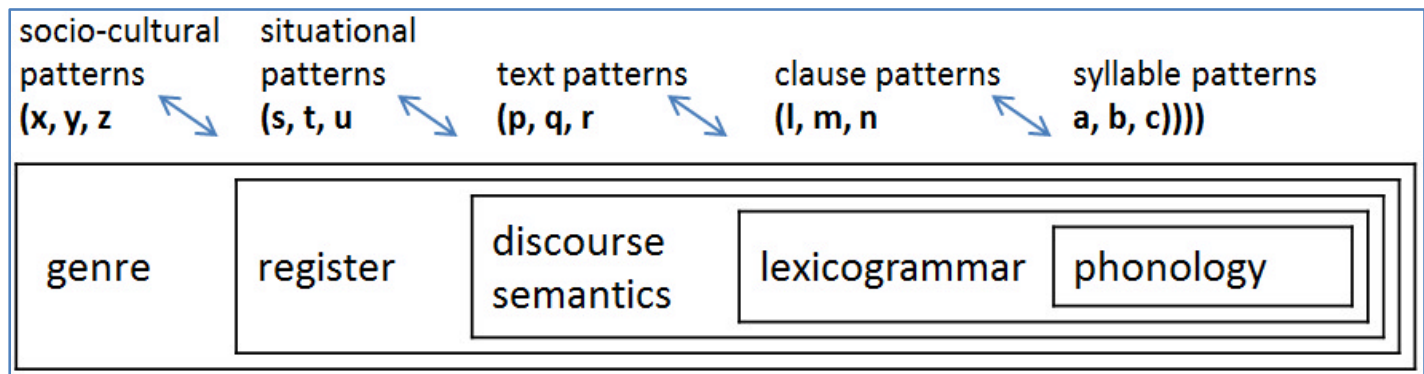

Fig-2: Metaredundant relation between strata (c.f. Quiroz, 2013, p. 21) adapted from Hao 2015:14

Based on this, Martin argues that "the advantage of the genre perspective is that it provides a more wholistic interpretation of text type which in turn makes it possible to account for the fafield, mode and tenor variables are never randomly combined but rather settle number of relatively stable combinations reflecting the system of social process engendering a speech community" [9]. This is quoted from Hao [10].

\section{MOOD STRUCTURE}

The mood structure of the clause refers to the organization of the functional constituents of the text.

The tenor of discourse, according to Eggins [2], is about the relationships between the interactants. And the kind of social role of an interactant has an effect on the language use.

Shakila [11] stresses that interpersonal metafunction includes a text's tenor of interactivity which is comprised with three components: the speakers/writer personae (whether the speaker or writer has a neutral attitude, which can be seen through the use of positive or negative language), social distance (how close the speakers are) and relative social status (whether they are equal in terms of power and knowledge on a subject). These two last components are applicable only to spoken texts, although a case has been made that these two can also apply to written texts.

The speech functions are related to typical mood in the clause as shown in the following table extracted from Eggins [7].

\begin{tabular}{|l|l|}
\hline Speech function & Typical mood in clause \\
\hline Statement & Declarative mood \\
\hline Question & Interrogative mood \\
\hline Command & Imperative mood \\
\hline Offer & Modulated interrogative mood \\
\hline Answer & Elliptical declarative mood \\
\hline Acknowledgment & Elliptical declarative mood \\
\hline Accept & Minor clause \\
\hline Compliance & Minor clause \\
\hline
\end{tabular}

From the foregoing, four main mood types are drawn. These are:

- the declarative mood: giving information by stating what is or happens;

- the interrogative mood: requesting information;

- the modulated interrogative mood: indirect/tempered request of information; 
And the imperative mood: getting someone to do something.

As for modality, it refers to the area of information that something can be affirmed or denied. And these pools are not the only possibilities. In between there is a number of choices of certainty, or usuality. Modality is subdivided into modalization and modulation. Eggins [7] contends that modalization is "the expression of the speaker's attitude towards what s/he's saying". Modalization involves probability and usuality. And the modal auxiliaries are can, could, should, may, shall, must, ought to, might, will, etc. As for modulation, it is used to express or argue about the obligation, necessity or inclination of proposals.

\section{METHODOLOGY AND DATA ANALYSIS}

To reach the objective earlier stated, the methodology guiding this research work has started with the critical reading of the speech under study. The choice of this speech is accounted for by the fact that it has been delivered late in the night by a woman leader to show how she cares for her people and is sleeplessness.

For the purpose of the analysis, the speech is subdivided into four parts. Each part deals with specific information. Then, the different parts are split into subsequent clauses. Drawing on the key below, the clauses are counted and tabularized accordingly. It is however, worth signalling that the practical analysis employs a mixed methodology; that is, it subsumes quantitative and quantitative methods. Through the quantitative method, statistical data (as regards the mood features) are recorded. As for the qualitative method, it is referred to for the analysis of the data obtained, and for the interpretation of the findings arrived at from the analysis.

Mood, Modality and adjuncts analysis of the speech

\section{Key:}

$\mathrm{S}=$ Subject, $\mathrm{F}=$ Finite, $\mathrm{Fn}=$ negative, Fms=modalized, $\mathrm{Fml}=$ modulated

$\mathrm{P}=$ Predicator, $\mathrm{Pml}=$ modulated Predicator,

$\mathrm{Pms}=$ modalised Predicator, $\mathrm{F} / \mathrm{P}=$ fused Finite and

Predicator, $\mathrm{mn}=$ Minor clause

$\mathrm{C}=$ Complement, $\mathrm{Ca}=$ attributive Complement

$\mathrm{A}=$ Adjunct, $\mathrm{Ac}=$ circumstantial, $\mathrm{Am}=$ mood,

Ao=comment, Ap=polarity, Av=vocative,

$\mathrm{Aj}=$ conjunctive, $\mathrm{At}=$ continuity, $\mathrm{Wh}=\mathrm{wh}$ element

\section{Queen Elizabeth II: (00:16)}

1. I (S)'m (F) speaking $(\mathrm{P})$ to you $(\mathrm{C})$ at what 2. [I (S) know (F/P)] (S) is (F) an increasingly challenging time, a time of disruption in the life of our country, (C) 3. a disruption (S) that has (F) brought $(\mathrm{P})$ [grief to some, financial difficulties to many, and enormous changes to the daily lives of us all]. (C) 4. I
(S) want $(\mathrm{F} / \mathrm{P})$ to thank everyone on the NHS frontline, as well as care workers (C) 5. and (Aj) those (S) carrying out $(\mathrm{F} / \mathrm{P})$ essential roles (C) 6. Who (S) selflessly continue (F/P) their day-to-day duties outside the home in support of us all. (C) 7. I(S)'m (F) sure (Ca) 8. the nation $(\mathrm{S})$ will $(\mathrm{Fml})$ join $(\mathrm{P})$ me in assuring you (C) 9. that $(\mathrm{Aj})$ [what $\operatorname{you}(\mathrm{S})$ do $(\mathrm{F})]$ is $(\mathrm{F})$ appreciated $(\mathrm{P}), 10$. and $(\mathrm{Aj})$ [every hour of your hard work] (S) brings (F/P) us closer to a return to more normal times.(C) 11. I (S) also want (F/P) to thank (P) those of you $(\mathrm{C})$ 12. who $(\mathrm{S})$ are $(\mathrm{F})$ staying $(\mathrm{P})$ at home, 13. thereby helping $(\mathrm{F} / \mathrm{P})$ to protect the vulnerable, $(\mathrm{C})$ 13. and $(\mathrm{AJ})$ sparing $(\mathrm{F} / \mathrm{P})$ many families (C) the pain $(\mathrm{S})$ already felt $(\mathrm{F} / \mathrm{P})$ by those $(\mathrm{C}) 15$. who $(\mathrm{S})$ have $(\mathrm{F})$ lost $(\mathrm{P})$ loved ones $(\mathrm{C})$.

\section{Queen Elizabeth II: (01:22)}

16.Together we $(\mathrm{S})$ are $(\mathrm{F})$ tackling $(\mathrm{P})$ this disease, $(\mathrm{C}) 17$. and $(\mathrm{Aj}) \mathrm{I}(\mathrm{S})$ want $(\mathrm{P})$ to reassure $(\mathrm{P})$ you $(\mathrm{C})$ that $(\mathrm{Aj}) 18$. if we $(\mathrm{S})$ remain $(\mathrm{F} / \mathrm{P})$ united and resolute, $(\mathrm{C})$ 19. then $(\mathrm{Ac})$ we $(\mathrm{S})$ will $(\mathrm{Fml})$ overcome (P) it.(C) 20. I (S) hope (F/P) in the years to come (C) 21. everyone (S) will (Fml) be able to take pride (C) 22 . in how (C) they (S) responded $(\mathrm{F} / \mathrm{P})$ to this challenge, $(\mathrm{C})$ 23. and $(\mathrm{Aj}) \mathrm{t}$ [hose $(\mathrm{S})$ who $(\mathrm{S})$ come $(\mathrm{F} / \mathrm{P})$ after us(C)] (S) will (Fml) say (P) [the Britons of this generation] $(\mathrm{S})$ were $(\mathrm{F} / \mathrm{P})$ as strong as any,(C) 24. that $(\mathrm{Aj})$ [the attributes of self-discipline, of quiet, good-humored resolve, and of fellow feeling still] (S) characterize $(\mathrm{F} / \mathrm{P})$ this country. (C) $25(\mathrm{~S})$. [[The pride in who] we $(\mathrm{S})$ are $(\mathrm{F})]$ 26. is $(\mathrm{F})$ not a part of our past, (C) 27. it (S) defines $(\mathrm{F} / \mathrm{P})$ our present and our future.(C)

\section{Queen Elizabeth II: (02:11)}

28. [The moments when $(\mathrm{C})$ the United Kingdom $(\mathrm{S})$ has $(\mathrm{F})$ come $(\mathrm{P})$ together to applaud $(\mathrm{P})$ its care (C) 29. and (Aj) essential workers (C)] (S) will $(\mathrm{Fml})$ be remembered $(\mathrm{P})$ as an expression of our national spirit, (C) 30. and (Aj) its symbol (S) will (Fml) be the rainbows (C) drawn (P) by children. (C) 31. [Across the Commonwealth and around the world,] (C) we $(\mathrm{S})$ have $(\mathrm{F})$ seen $(\mathrm{P})$ [heartwarming stories of people coming together to help others,] (C) 32. be (F) it (S) through delivering $(\mathrm{P})$ [food parcels and medicines, ] (C) checking $(\mathrm{P})$ on neighbors, $(\mathrm{C}) 33$. or converting $(\mathrm{P})$ businesses $(\mathrm{C})$ to help $(\mathrm{P})$ the relief effort.(C) 34. And (Aj) though self-isolating $(\mathrm{S})$ may $(\mathrm{Fml})$ at times $(\mathrm{Ac})$ be $(\mathrm{P})$ hard,(C) [many people of all faiths and of none] $(\mathrm{S})$ are $(\mathrm{F})$ discovering $(\mathrm{P}) 35$. that $(\mathrm{Aj})$ it $(\mathrm{S})$ presents $(\mathrm{F} / \mathrm{P})$ an opportunity $(\mathrm{C})$ to slow down $(\mathrm{P})$, pause $(\mathrm{P})$ and reflect $(\mathrm{P})$ in prayer or meditation.(C)

\section{Queen Elizabeth II: (03:06)}

36. It $(\mathrm{S})$ reminds $(\mathrm{F} / \mathrm{P})$ me of the very first broadcast (Ca) 37. I (S) made (F/P) in 1940,(C) helped (F/P) by my sister. (Ca) 38. [We as children] (S) spoke $(\mathrm{F} / \mathrm{P})$ from here at Windsor to children (Ac) 39. who (S) had $(\mathrm{F})$ been evacuated $(\mathrm{P})$ from their homes (C) 40. and (Aj) sent away (F/P) for their own safety. (C) 41 . 
Today, (Ac) once again, many (S) will (Fml) feel (P) [a painful sense of separation from their loved ones,] 42 . but $(\mathrm{Aj})$ now as then, we (S) know (F/P) deep down (C) 43. that $(\mathrm{Aj})$ it $(\mathrm{S})$ is $(\mathrm{F})$ [the right thing to do] $(\mathrm{C}) .44$. While (At) we $(\mathrm{S})$ have $(\mathrm{F})$ faced $(\mathrm{P})$ challenges $(\mathrm{C})$ before, (Ac) 45. [this one] (S) is (F) different. (C) 46. This time (Ac) we (S) join (F/P) [with all nations across the globe in a common endeavor] $(\mathrm{C}) .47$. Using $(\mathrm{F} / \mathrm{P})$ the great advances of science and our instinctive compassion to heal $(\mathrm{P})$, we $(\mathrm{S})$ will $(\mathrm{F})$ succeed $(\mathrm{P}), 48$. and $(\mathrm{Aj})$ that success $(\mathrm{S})$ will $(\mathrm{Fml})$ belong $(\mathrm{P})$ to every one of us. (C) 49. We (S) should (Fml) take (P) comfort (C) 50. That (Aj) while we (S) may (Fml) have (P) more still to endure, (C) 51. [better days] (S) will $(\mathrm{Fml})$ return $(\mathrm{P})$. 52. We $(\mathrm{S})$ will $(\mathrm{Fml})$ be $(\mathrm{P})$ with our friends again $(\mathrm{C})$. 53. We $(\mathrm{S})$ will $(\mathrm{F})$ be $(\mathrm{P})$ with our families again $(\mathrm{C})$. 54. We $(\mathrm{S})$ will $(\mathrm{F}: * \mathrm{ml})$ meet $(\mathrm{P})$ again. 55. But $(\mathrm{Aj})$ for now $(\mathrm{Ac}), \mathrm{I}(\mathrm{S})$ send $(\mathrm{F} / \mathrm{P})[\mathrm{my}$ thanks and warmest good wishes to you all] (C).

Findings after the Analysis

\begin{tabular}{|l|l|l|}
\hline Mood Types & Number & Percentage \\
\hline Full declarative & $\mathbf{5 5}$ & $\mathbf{1 0 0 \%}$ \\
\hline Full polar interrogative & $\mathbf{0 0}$ & $\mathbf{0 0 \%}$ \\
\hline Elliptical interrogative & $\mathbf{0 0}$ & $\mathbf{0 0 \%}$ \\
\hline Full wh-interrogative & $\mathbf{0 0}$ & $\mathbf{0 0 \%}$ \\
\hline Elliptical wh-interrogative & $\mathbf{0 0}$ & $\mathbf{0 0 \%}$ \\
\hline Total ranking clauses & $\mathbf{5 5}$ & $\mathbf{1 0 0 \%}$ \\
\hline Modality & & \\
\hline Modalization & $\mathbf{1 1}$ & $\mathbf{0 6 , 6 \%}$ \\
\hline Modulation & $\mathbf{0 5}$ & $\mathbf{0 2 , 7 5 \%}$ \\
\hline Negation & $\mathbf{0 0}$ & $\mathbf{0 0 \%}$ \\
\hline Total ranking clauses & $\mathbf{5 5}$ & $\mathbf{1 0 0 \%}$ \\
\hline
\end{tabular}

The above table shows the distribution of Mood Types and modality in the speech of Queen Elizabeth II. It is obvious from the table above that declarative is the only mood type deployed in the speech, with a rate of $100 \%$. Declarative clauses function as statement for exchanging information.

As for modality types, modalization is essentially resorted to within 11 occurrences. This implies that Queen Elizabeth II is presenting the reader with what she is encoding as factual-information, being sometimes uncertain about the outcome of the sickness.

Modulation is displaed 5 times. This shows how Queen Elisabeth II gives orders to the citizen to follow the instructions to avoid the illness.

\section{DISCUSSION OF THE FINDINGS}

To begin with, it should be highlighted that a novel coronavirus (SARS-CoV-2) has emerged in 2019 in Wuhan in China. Previously, people believe, at the beginning, it was an epidemic but early 2020, it has been discovered to be a pandemic. It has become a global health concern. This virus is transmitted from human to human via droplets, contaminated hands or surface. Then some measures have been taken to reduce its spread as it causes death especially amongst the old people. Therefore, some increased awareness started from many people and leaders, be they political or religious. These latter appeal their citizens to follow some prescribed measures to overcome the pandemic.

Here is one of the speeches proclaimed by one of the leaders, to name Britain's Queen Elizabeth II. In fact Queen Elizabeth II makes one of her rare speeches to the Great Britain and the Commonwealth. In fact she only addresses a speech on Christmas day to the Commonwealth. That is to say this is a special occasion which breaks her habits. A Coronavirus or COVID-19 made her deliver a speech very late in the night.

This is a spoken discourse which has been transcribed in four (4) sequences. The first speech was held at 00:16, the second at 1:22, the third at 2:22 and the last one at 3:06. Queen Elizabeth used some short speeches very late in the night to show her concern about what is happening.

In the first sequence, Queen Elizabeth II speaks about the adjustments of the ways of life of her people. She finds it as "a time of disruption in the life of our country". This leads to some financial difficulties. She also encourages the frontline actors who put their lives on the line to help people defeat that powerful virus. In addition, she pays attention to the people staying at home to take care of the most vulnerable. In fact, she thanks all the citizenry. Meanwhile she uses the metaphors of modality 'I'm sure' to call all of them to thank the citizenry for the law-abiding. It expresses a high certainty of the end of this pandemic. There is confidence in her words. This pandemic will not be eternal. It will stop.

The second sequence, she uses three times the modal verb 'will': 18. Then we will overcome it; 20. Everyone will be able to take pride and 22 and those who come after us will say. Queen Elizabeth believes they can defeat the virus and be congratulated by the future generations of their country. She shows her solidarity and hope about the return to normalcy and the attitudes of the futures generations on how the present people fight the Coronavirus. For her, her people will overcome the fight against this virus and survive. She calls for unity to stand against the COVID-19. She also reminds them of such attributes as self-discipline, quiet, good-humoured resolve, and fellow feeling.

In the third sequence, three modal verbs have been used in 29. (Will be remembered as), 30. (and its symbol will be the rainbows) and in 34. (And though self-isolating May at times is hard). It is in the same vein as the second sequence. The use of modalization shows that the frequency of contact is low. However, she casts a call to her compatriots that self-isolating, 
though hard, presents an opportunity to slow down, pause and reflect in payer or meditation.

Nine modals have been used in the final sequence. There she recalled her first broadcast in 1949 with her sister. They addressed other children displaced by the Second World War.

Queen Elisabeth II has used some modal verbs such as: can, may, could, will, to express the face-toface conversation between her and her people. Queen Elisabeth plays the entire role. She has an unequal power relation with her audience. She acts as the one who have the knowledge about the Covid-19 and the instructions to follow to come through it.

The presence of modulation implies the judgment of Queen Elizabeth II. She does not express the degree of inclination in a clear manner. But while reading carefully the speech, one understands that she does it in a subtle manner.

Queen Elizabeth II is the initiator of the speech which intends to give information to her citizens in the exacting moments of Covid-19. She is urging the citizenry to follow the preventive measures in these trying times and times of panic to stop the spread of the Coronavirus. There is lack of reciprocity. This means there is unequal power between her and her people.

As a political leader, Queen Elizabeth II is not just giving information. She shows her concern about the situation prevailing in the World. She expresses her attitude about what is being said. She asked her people to continue to be patient, to support all the recommendations and prescribed measures though they are difficult to bear. Queen Elizabeth II requires that the Britons be vigilant and adhere to the measures so that each of them play his part to retrench the spread of the virus; that will enable them to hasten the return to normalcy of life. Therein, the most encountered typical mood in the clauses is the declarative Mood because the text is made up of statements. It is about giving information. Queen Elizabeth II is giving some useful information to tackle the Coronavirus from the World. She cleverly uses statements to get things done. She does not use command in her speech. But she wants her citizens to apply the preventive measures to the Coronavirus.

Finally, the speech functions used by Queen Elizabeth II are persuading, motivating, inviting, ordering, proposing and enticing the citizens to apply the preventive measures to the Coronavirus. The interpersonal metafunction is based on social roles and relations. So Queen Elizabeth II is playing her role and reinforces the relations between herself and her citizens.

She uses the pronoun "I" in almost the whole speech. The use of the first person pronoun portrays
Queen Elizabeth II as an insider to the situation. She is concerned about the current situation. She then shows her proximity with the sick people and the World. Notice that the first-person narrative is used therein.

Queen Elizabeth II uses her speech in a special context which is the context of the pandemic. In fact, context has a huge role in the speech because due to context, she is obliged to break her habits. Queen Elizabeth since 1952 usually addresses her people once a year. This is the $5^{\text {th }}$ time she has spoken specifically. Although the speech is addressed to the Britons, it is also appealed to anyone watching her. She stressed on the fact that they have faced some challenges but that this one is different.

\section{CONCLUSION}

The main purpose of this paper was to examine the relationship between linguistic structures and socially constructed meanings in the speech by Queen Elisabeth II during this pandemic, through linguistic analysis. For Amoussou [8], 'the tenor of discourse is used to designate the role relation of power and solidarity between the interactants, speakers/listeners, addresser/addressee, writer or narrator/reader of the writer/speaker's attitude to the subject matter...etc'. From the analysis of mood and modality, the exploration of the language used by Queen Elizabeth II, the power relationships between her and her people, the solidarity and proximity in her speech are being revealed. In fact, what is shown in this paper is the functions of language in human beings' relationships. Queen Elisabeth II is raising the question of fear of what could happen due to this virus, the necessity for people to protect themselves, the problems her people are facing, the economic recession and the future social relations. The present study also indicated how the social status influenced language of Queen Elizabeth II.

On the whole, this paper has helped to unveil the hidden meaning in Queen Elisabeth II's speech at the crucial times of the Coronavirus. It has also showed how she uses language to express the fears of human beings in front of a certain virus that has to be fight without guns but by certain behaviors in a given context. Through an in-depth study of this speech, it provides insights into the plight of human beings during these trying times and the lull expected. This speech helped to understand some of the common social issues in the world as a whole during this crucial pandemic.

\section{REFERENCE}

1. Fontaine L. Analysing English grammar: A systemic functional introduction. Cambridge University Press; 2012 Oct 25.

2. Eggins S. Introduction to systemic functional linguistics. A\&C Black; 2004.

3. Halliday MA. Linguistic function and literary style: An inquiry into the language of William Golding's 
The Inheritors. Essays in modern stylistics. 1981:325-60.

4. Halliday MA, Hasan R, Hasan R. Language, text and context. Victoria: Derkin University. 1985.

5. Halliday M, Matthiessen CM, Matthiessen C. An introduction to functional grammar. Routledge; 2014 Feb 4.

6. Halliday M, Matthiessen CM, Matthiessen C. An introduction to functional grammar. Routledge; 2014 Feb 4.

7. Eggins S. An Introduction to Systemic Functional Linguistics. London: Pinter Publishers; 1994.

8. Amoussou YC. Discourse Tenor, Context and Character in The Lawyer's Monster Parable (Petals of Blood). In Particip'Action. 2014; 6(1), 147-170.
9. Sala-i-Martin X, Sachs J. Fiscal federalism and optimum currency areas: evidence for Europe from the United States. National Bureau of Economic Research; 1991 Oct 1.

10. Marfo CO. Exploiting the exploiter: Some violations of society's expectations in Beyond the Horizon and The Housemaid. 3L: Language, Linguistics, Literature®. 2015 Mar 19;21(1).

11. Nur S. Analysis of interpersonal metafunction in public speeches: A case study of Nelson Mandela's presidential inauguration speech. The International Journal of Social Sciences. 2015;30(1):52-63. 